\title{
Dampak Pemanasan Global Terhadap Keterawatan \\ Candi Borobudur
}

\author{
Oleh : \\ Wiwit Kasiyati, S.S dan Brahmantara, S.T \\ Balai Konservasi Peninggalan Borobudur
}

\section{A. Latar Belakang}

Candi Borobudur sebagai Warisan Budaya Dunia berada di alam terbuka dan struktur bangunannya berdiri di atas bukit, sehingga faktor lingkungan sangat berpengaruh terhadap kelestariannya. Candi Borobudur dibangun dengan material sebagian besar terbuat dari batu andesit. Keberadaan benda cagar budaya ini tidak akan mungkin terlepas dari kondisi lingkungannya. Interaksi antara benda cagar budaya dengan lingkungannya akan terjadi secara alami dan tidak akan dapat ditanggulangi. Sebagai akibatnya akan terjadi proses adaptasi dengan lingkungannya, dampak yang ditimbulkan berwujud proses degradasi berupa kerusakan maupun pelapukan.

Kerusakan dan pelapukan mempunyai pengertian yang hampir sama, akan tetapi secara teknis terdapat perbedaan. Kerusakan material adalah suatu proses perubahan bentuk yang terjadi pada suatu benda di mana jenis, sifat fisik, dan sifat kimiawinya masih tetap. Sementara pelapukan adalah suatu proses penguraian dan perubahan dari bahan asli ke material lain di mana jenis, sifat fisik serta kimiawinya sudah mengalami perubahan. Pelapukan batu dapat disebabkan olch faktor internal maupun eksternal. Salah satu faktor eksternal adalah iklim, sedangkan faktor iklim antara lain air hujan dan panas matahari.

Candi Borobudur telah mengalami kerusakan dan pelapukan yang disebabkan oleh faktor internal meliputi struktur, tanah dasar, material, dan belan, serta faktor eksternal meliputi iklim, air, pertumbuhan mikrobiologi, ulah manusia, dan bencana alam. Faktor internal sebagian besar sudah dapat ditangani dalam pemugaran Candi Borobudur yang berlangsung dari tahun $1973 \quad 1983$ yaitu perbaikan struktur, pemasangan "concrete slab" pada dasar bangunan serta melaksanakan konservasi material bangunan. Namun untuk faktor eksternal sangat sulit ditangani secara tuntas karena Candi Borobudur berada di alam terbuka sehingga faktor iklim sangat berpengaruh terhadap material bangunannya.

Faktor eksternal diantaranya perubahan suhu dan kelembapan yang tinggi dan selalu berubah-ubah setiap saat akan menyebabkan kondisi batu tidak stabil yang akhirnya dapat mengakibatkan terjadinya keretakan, pecah, dan sebagainya. Air hujan yang membasahi material dapat menyebabkan kelembapan material menjadi tinggi. Keadaan tersebut dapat memicu pertumbuhan jasad (ganggang, lumut, jamur kerak) pada permukaan material. Akibat selanjutnya material tersebut akan mengalami kerapuhan, berlubang, menyusut, pecah, patah, dan lain sebagainya.

()leh karena itu diperlukan beberapa usaha penanggulangan untuk menghindari sedini mungkin proses kerusakan ian pelapukan bangunan Candi Borobudur. Salah satunia dengan melaksanakan kegiatan monitoring kerusatian batu, usaha petawatan demi kelestarian Candi Borobudur, dan monitoring ikline melalui data klimatologi untuk mengetahui kondisi makro dan mikro Candi Borobudur beserta kawasannya.

Dengan adanya pemanasan global yang dirasakan oleh seluruh dunia termasuk Indonesia yang berakibat adanya perubahan iklim global, maka perlu dilakukan evaluasi secara serius terhadap iklim di kawasan Borobudur pada umumnya dan Candi Borobudur khususnya untuk mengantisipasi sedini mungkin apabila perubahan iklim tersebut berdampak pada kerusakan batubatu Candi Borobudur. Hal ini perlu dilakukan karena Candi Borobudur merupakan Warisan Budaya Dunia sehingga hal-hal yang berdampak negatif terhadap kelestariannya segera ditangani.

\section{B. Pengertian Klimatologi}

Menurut pengertian umum klimatologi adalah ilmu pengetahuan alam yang mempelajari tentang iklim. Pengertian iklim adalah deskripsi dari keadaan cuaca rata-rata atau keadaan cuaca jangka panjang pada suatu daerah atau kawasan. Cuaca adalah keadaan fisik atmosfer pada saat yang pendek dan pada daerah tertentu. Iklim dan cuaca merupakan salah satu unsur lingkungan hidup yang sangat besar pengaruhnva terhadap kehidupan manusia. Unsur-unsur cuaca dapat berinteraksi dengan faktor yang lain dan menimbulkan proses kerusakan terhadap benda cagar budara.

Klimatologi dapat dibagi menjadi beberapa cabang diantarania vaitu makro klimatologi dan mikro klimatologi. Pengertian makero klimatologe adalah ilmu rang mempelajari kendisi iklim dalam 
lingkup yang luas pada suatu daerah dengan radius $+10 \mathrm{~km}$ dari stasiun klimatologi, sedangkan mikro klimatologi adalah ilmu yang mempelajari iklim dalam lingkup yang sempit pada lapisan udara terdekat dengan permukaan bumi. Unsur iklim makro meliputi suhu udara, kelembapan udara, tekanan udara, hujan, penyinaran matahari, penguapan air, dan angin, sedangkan unsur iklim mikro meliputi suhu udara, kelembapan udara, dan suhu batu.

Untuk pemantauan kondisi iklim di lingkungan Candi Borobudur, sejak prapemugaran yaitu pada tahun 1970 dibangun stasiun klimatologi Borobudur. Stasiun klimatologi ini berlokasi di sebelah Tenggara Candi Borobudur. Pemantauan dan perekaman data iklim telah dilakukan secara intensif sejak berdirinya stasiun sampai sekarang. Hasil pengumpulan data klimatologi telah banyak menunjang jalannya kegiatan perawatan Candi Borobudur selama pemugaran sampai sekarang. Evaluasi data yang diperoleh digunakan untuk membuat prakiraan sifat iklim di kawasan Borobudur dan sekitarnya. Kegiatan pengamatan klimatologi kawasan Borobudur dilakukan atas kerjasama BMG (Badan Meteorologi dan Geofisika) Jakarta dan Stasiun Klimatologi Semarang guna menunjang evaluasi iklim global secara nasional.

Sekarang ini pemantauan iklim mikro di sekitar Candi Borobudur menggunakan dua stasiun klimatologi. Stasiun klimatologi pertama berada di bukit jaten yang telah terpasang sejak tahun 1970 yang sistem pengoperasiannya secara manual. Sejak tahun 2005 Balai Konservasi Peninggalan Borobudur mendapat bantuan alat klimatologi baru berlokasi di Balai Konservasi Peninggalan Borobudur yang sistem pengoperasiannya sudah menggunakan digitalisasi. Alat tersebut bantuan dari BMG dengan nama AWS (Automatic Weather System). Namun alat AWS tersebut kondisi sekarang sering mengalami kerusakan, sehingga data yang dipakai untuk penelitian ini hanya menggunakan data manual dari stasiun klimatologi di bukit jaten. Kondisi iklim di Borobudur dibedakan menjadi dua yaitu iklim makro (kondisi iklim dalam lingkup yang lebih luas di suatu kawasan dengan radius $\pm 10 \mathrm{~km}$ di mana stasiun klimatologi Borobudur sebagai titik pusatnya) dan iklim mikro (kondisi iklim dalam lingkup kecil dalam hal ini adalah Candi Borobudur).

\section{Pengaruh Iklim Terhadap Pertumbuhan Jasad}

$\mathrm{Keberadaan} \mathrm{Candi}$

Borobudur yang terletak di alam terbuka, kondisi batu candi sangat dipengaruhi oleh iklim setempat. Unsur-unsur iklim yang mempengaruhi kerusakan batu candi adalah suhu udara, angin, kelembapan udara, hujan, dan penyinaran matahari. Amplitudo suhu udara yang tinggi pada siang dan malam hari yang berlangsung dalam waktu lama akan mengakibatkan batu menjadi retak. Angin juga dapat menimbulkan kerusakan karena angin membantu penyebaran spora-spora jasad tingkat rendah (lumut/ moss, ganggang/ algae dan jamur kerak/ lichen) ke permukaan batu sehingga akan muncul pertumbuhan jasad.

Kelembapan udara merupakan pemacu pertumbuhan jasad pada batu, di mana jasad tersebut merupakan faktor penyebab kerusakan batu. Dari data klimatologi curah hujan di kawasan Candi Borobudur tergolong tinggi tiap tahunnya sehingga air hujan mempengaruhi dalam proses kerusakan batu. Kerusakan yang ditimbulkan oleh air hujan yaitu penggaraman (efflorenscence), erosi (pengikisan) pada permukaan batu, dan pemacu populasi jasad. Sinar matahari dapat merusak batu dan pemacu pertumbuhan jasad tingkat rendah, di mana jasad-jasad tersebut memerlukan sinar matahari secara langsung maupun tidak langsung dalam proses kehidupannya.

$\mathrm{S}$ in a $\mathrm{r}$ a $\mathrm{tah}$ a $\mathrm{ri}$ dimanfaatkan oleh tumbuhan untuk berfotosintesis. Fotosintesis adalah suatu proses biokimia yang dilakukan tumbuhan, algae, dan beberapa jenis bakteri untuk memproduksi energi terpakai (nutrisi) dengan memanfaatkan energi cahaya. Hampir semua makhluk hidup bergantung dari energi yang dihasilkan dalam fotosintesis. Akibatnya fotosintesis menjadi sangat penting bagi kehidupan di bumi. Fotosintesis juga berjasa menghasilkan sebagian besar oksigen yang terdapat di atmosfer bumi. Organisme yang menghasilkan energi melalui fotosintesis (photos berarti cahaya) disebut sebagai fototrof. Fotosintesis merupakan salah satu cara asimilasi karbon karena dalam fotosintesis karbon bebas dari $\mathrm{CO}_{2}$ diikat (difiksasi) menjadi gula sebagai molekul penyimpan energi (http://id.wikipedia.org /wiki/fotosintesa).

\section{Kondisi Iklim Mikro dan Makro Borobudur (1970 2007)}

a. Suhu udara (minimum, maksimum, rata-rata) Berdasarkan data klimatologi, suhu udara minimum $10,0^{\circ} \mathrm{C}$ pada tahun 1970, suhu udara maksimum $37,0^{\circ} \mathrm{C}$ pada tahun 1972, 1980, dan 1993. Suhu udara rata-rata terendah $24,9{ }^{\circ} \mathrm{C}$ pada tahun 1976 dan 
dan tertinggi $26,4^{\circ} \mathrm{C}$ pada tahun 1998. Di bawah ini grafik suhu udara minimum, maksimum, dan rata-rata.

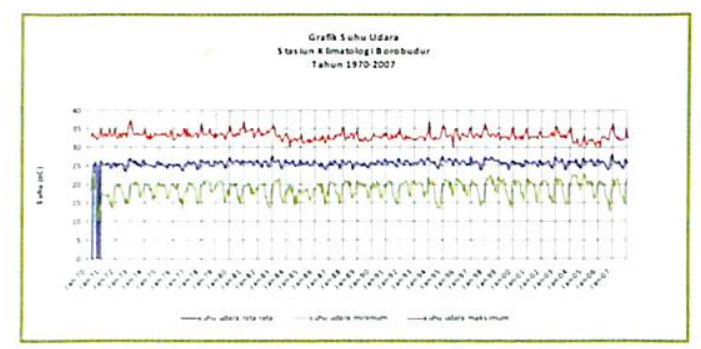

b. Kelembapan udara rata-rata Berdasarkan data klimatologi, kelembapan udara selama pemugaran berkisar $75 \%$ - $83 \%$ dengan rata-rata $79 \%$. Secara global kelembapan udara dalam masa pascapemugaran berkisar $75 \%$ - 83\% dengan rata-rata $80 \%$. Di bawah ini grafik kelembapan udara rata-rata.

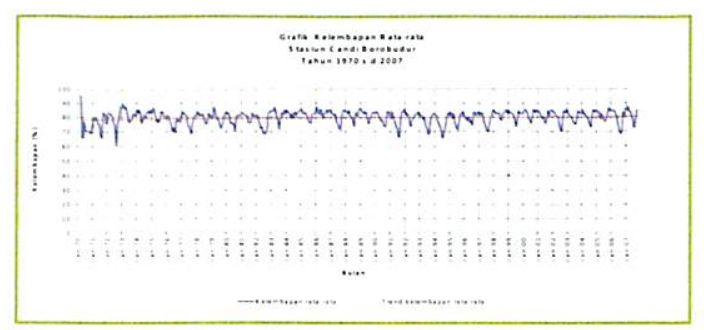

c. Jumlah curah hujan

Berdasarkan data klimatologi, curah hujan tertinggi pada bulan November 1995 sebesar 621 $\mathrm{mm}$. Dengan mengukur jumlah curah hujan dapat diketahui perubahan musim yang terjadi. Curah hujan di sekitar Borobudur termasuk dalam tipe iklim tropis agak basah. Data curah hujan dapat digunakan dalam membuat perencanaan penentuan pelaksanaan tindakan konservasi dalam perawatan Candi Borobudur. Di bawah ini grafik jumlah curah hujan.

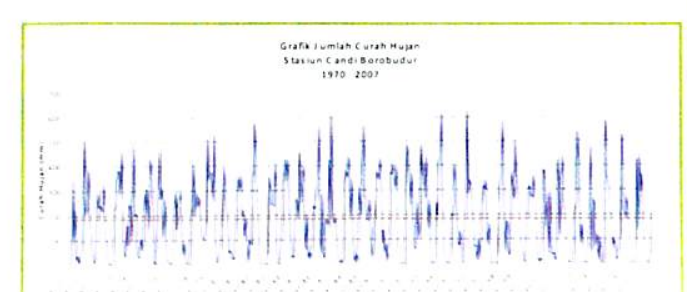

d. Arah dan kecepatan angin Berdasarkan data klimatologi, arah dan kecepatan angin tahun 19701983 tidak ada data yang terekam oleh alat klimatologi. Baru pada tahun 19842007 terdata kecepatan angin tertinggi $4,2 \mathrm{~m} / \mathrm{s}$ pada tahun 1984 dan terendah tahun 2007 $1,4 \mathrm{~m} / \mathrm{s}$. Di bawah ini grafik arah dan kecepatan angin.

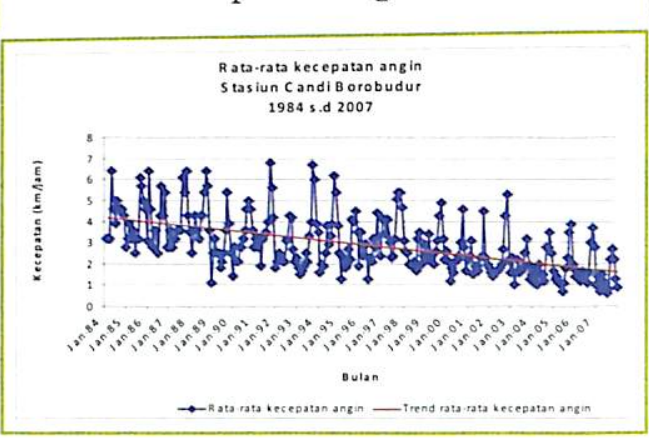

e. Lama penyinaran

Berdasarkan data klimatologi, rata-rata penyinaran matahari tahunan berkisar $58 \%$. Penyinaran matahari pada umumnya antara bulan April s/d November pada umumnya melebihi 50\% sedangkan pada bulan Desember s/d Maret umumnya lebih kecil dari 50\%. Posisi geografis Borobudur yang berada pada bagian Selatan katulistiwa menyebabkan distribusi penyinaran matahari terhadap dinding-dinding candi tidak merata. Dinding candi sebelah Utara lebih banyak menerima sinar matahari dibandingkan sisi Selatan, sedangkan sisi Timur dan Barat sama menerima sinar matahari. Di bawah ini grafik lama penyinaran.

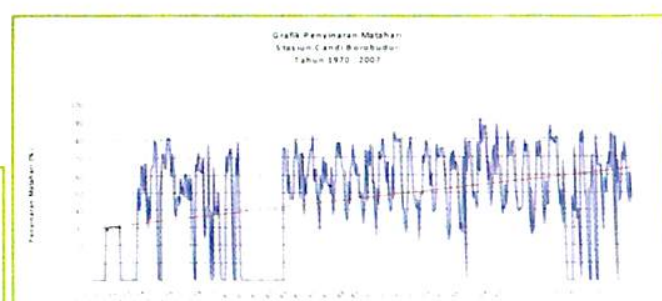

F. Jumlah penguapan air

Berdasarkan data klimatologi, jumlah penguapan air tertinggi terjadi tahun 2006 mencapai $1533,8 \mathrm{~mm}$ dengan rata-rata $127,8 \mathrm{~mm}$. Jumlah penguapan terendah terjadi tahun 1970 mencapai 437,7 $\mathrm{mm}$ dengan rata-rata $43,8 \mathrm{~mm}$. Di bawah ini grafik jumlah penguapan air.

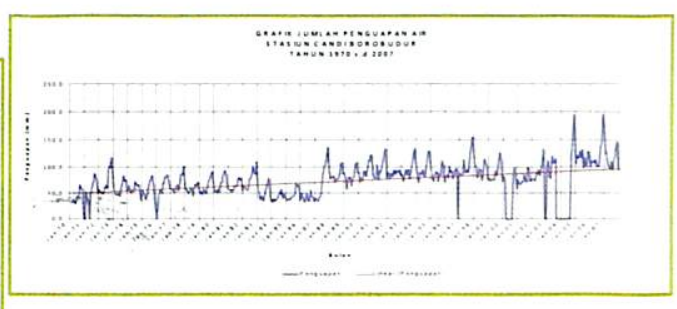

g. Intensitas penyinaran matahari Berdasarkan data klimatologi, tidak banyak data terekam dari tahun 19701980 dan tahun 19982007 dikarenakan peralatan yang ada rusak. Data yang dapat diperbandingkan hanya dari tahun 19811997. Intensitas penyinaran tertinggi pada tahun 1984 rata-rata 450 g.cal/ menit dan terendah ratarata 180 g.cal/ / menit pada tahun 1997. Intensitas penyinaran yang tinggi kemungkinan akan berpengaruh pada terjadinya proses penggaraman dan retakan mikro pada batu candi. Di bawah ini grafik intensitas penyinaran matahari.

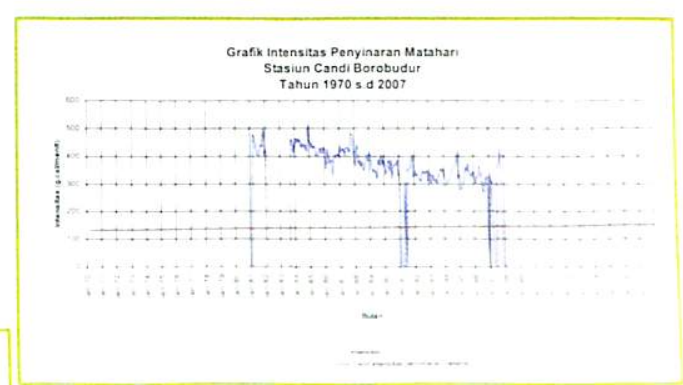

E. Kondisi Kerusakan BatuBatu Candi Borobudur (1984 2007)

Proses kerusakan dan pelapukan terhadap benda cayar budava dapat disebabkan oleh faktor internal dan eksternal. 
Kerusakan dan pelapukan akibat faktor internal diantaranya material yang digunakan, beban, struktur, tanah dasar, sedangkan pengaruh eksternal diantaranya ulah manusia, bencana alam, dan cuaca atau iklim. Diantara faktor tersebut di atas, cuaca atau iklim sampai saat ini tidak dapat dikendalikan oleh manusia. Unsur-unsur cuaca dapat berinteraksi dengan faktor yang lain dan menimbulkan suatu proses yaitu kerusakan fisis atau mekanis, pelapukan kimiawi, dan pelapukan biologi.

Data kerusakan dan pelapukan terhadap batu-batu Candi Borobudur yaitu :

a. Pertumbuhan jasad

Air hujan yang membasahi batu d a pat menyebabkan kelembapan material menjadi tinggi. Pertumbuhan jasad (lumut/ moss, ganggang/ algae, jamur kerak/ lichen), disebabkan oleh kelembapan yang tinggi sehingga lumut, ganggang, dan jamur kerak dengan cepat akan tumbuh pada permukaan batu. Posisi Candi Borobudur berada di sebelah Selatan katulistiwa sehingga bagian batu candi yang berada di sisi Utara akan lebih banyak terkena sinar matahari daripada sisi Selatan, demikian pula sebaliknya. Pada bagian batu candi yang terkena sinar matahari suhu menjadi tinggi, sedangkan yang ternaungi di sisi Selatan suhu menjadi rendah, penguapan air semakin kecil, sehingga kelembapan menjadi tinggi. Dengan adanya perbedaan tersebut, maka metode pelaksanaan konservasi pada masing-masing sisi juga a kan berbeda. Dat a pertumbuhan jasad dapat dilihat pada grafik di bawah ini :

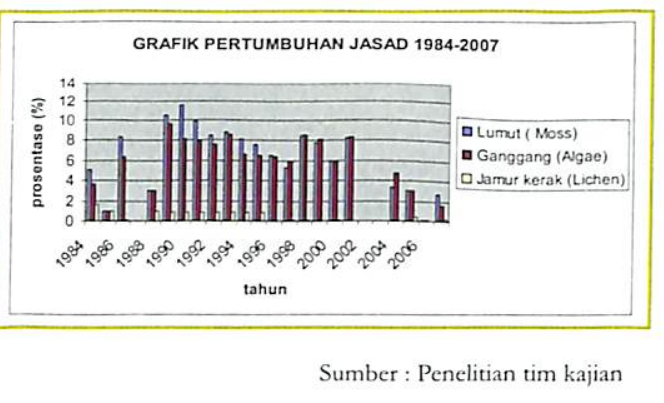

B. Postule dan lubang alveol

Postule atau bisul-bisul pada batu merupakan assosiasi antara lumut dan algae. Penyakit batu ini banyak dijumpai pada daerah endapan garam yang pecah dan membentuk lubang alveol. Data postule dan lubang alveol dapat dilihat pada grafik di bawah ini : proses alami yang sampai saat ini masih terus berlangsung. Pengelupasan, disebabkan oleh fluktuasi suhu sehingga terjadi penyusutan dan pengembangan. Pengelupasan terbanyak terjadi pada batu yang beroker dan terdapat lapisan endapan garam. Untuk menangani pengelupasan sampai saat ini belum dapat diatasi. Salah satu tindakan preventif yang dilakukan adalah membersihkan endapan garam dan menangani kebocoran pada dinding candi. D a t a pengelupasan dapat dilihat pada grafik di bawah ini :
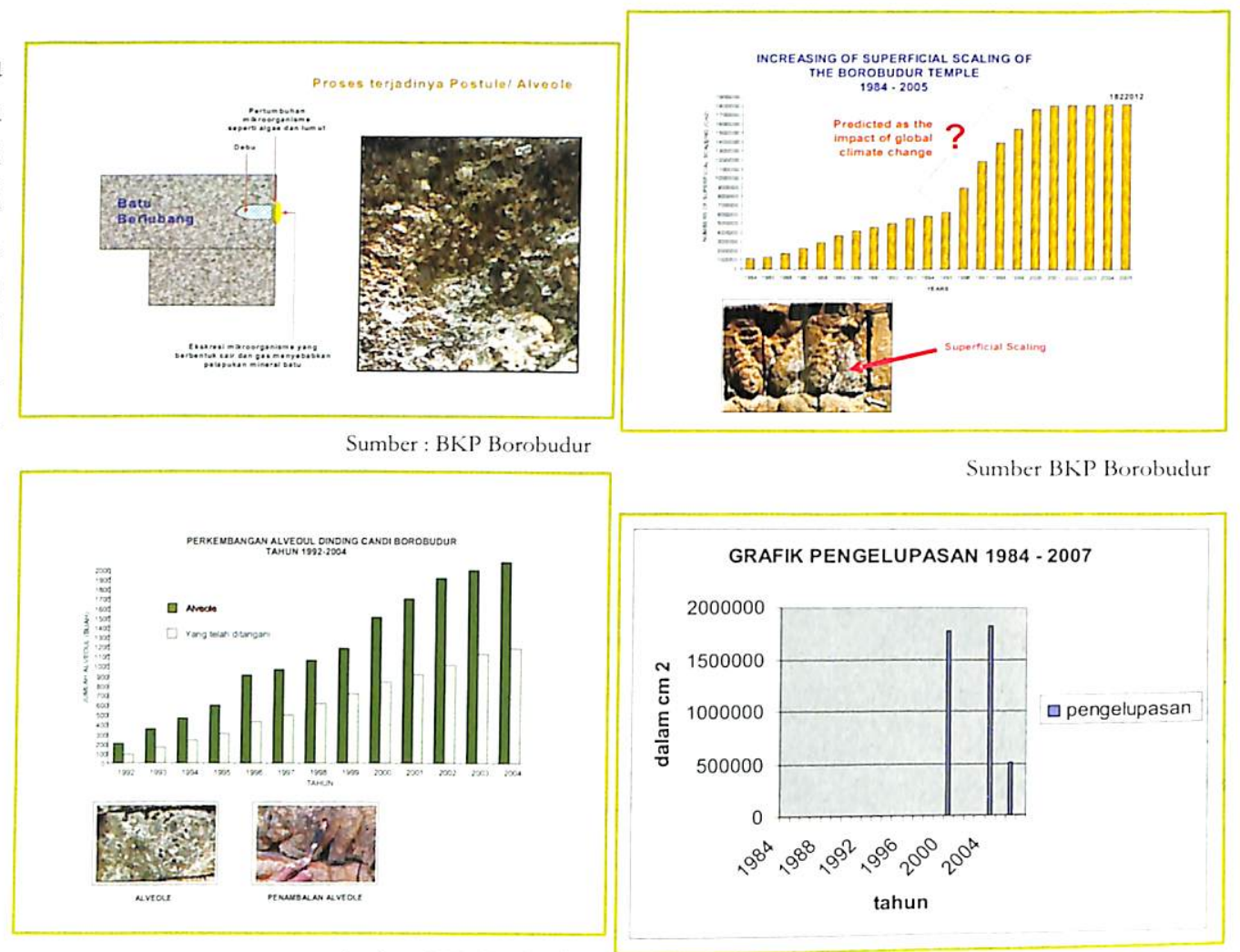

Sumber BKP Borobudur
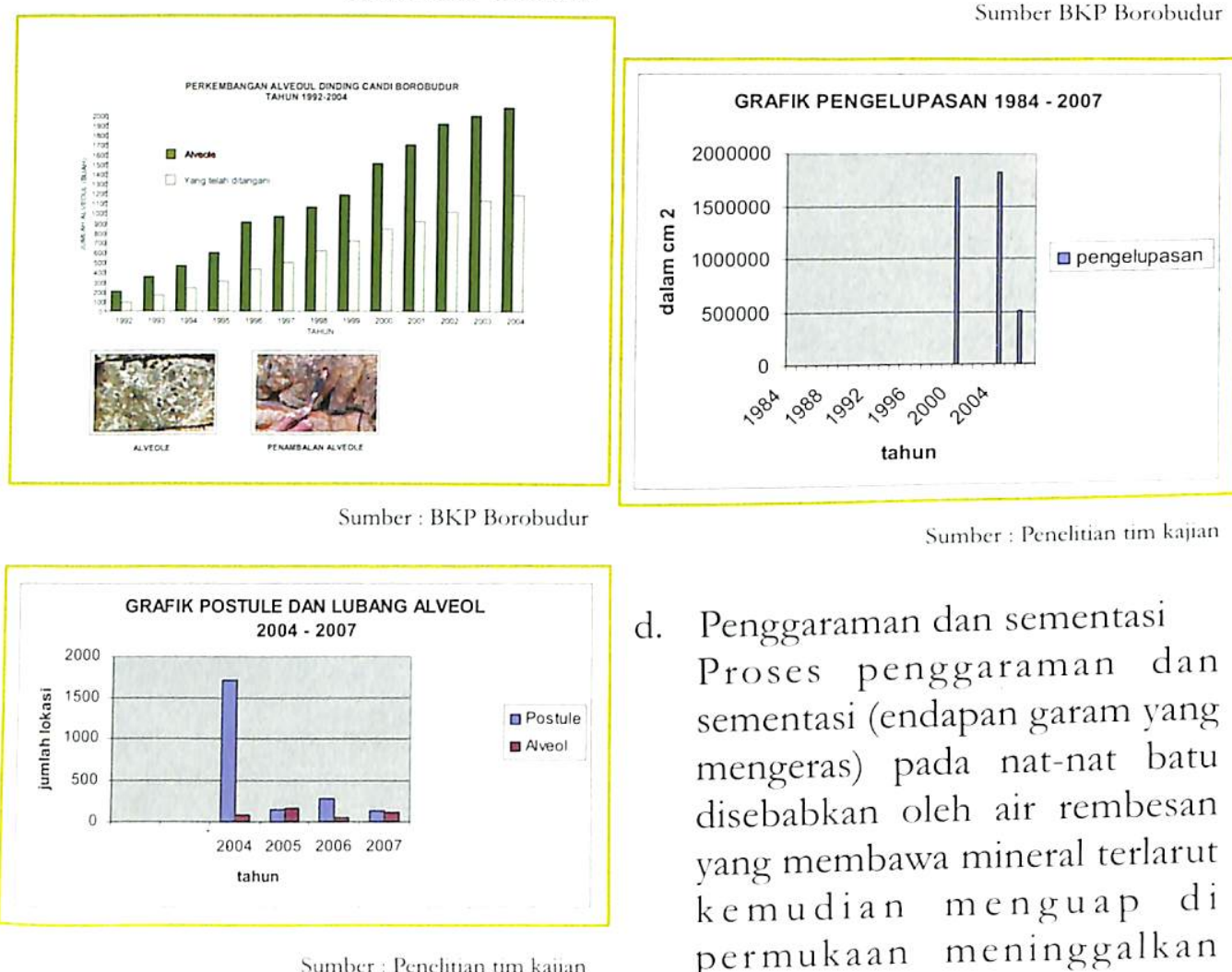

d. Penggaraman dan sementasi Proses penggaraman dan sementasi (endapan garam yang mengeras) pada nat-nat batu disebabkan oleh air rembesan yang membawa mineral terlarut kemudian menguap di permukaan meninggalkan endapan. Penggaraman, disebabkan oleh adanya

c. Pengelupasan

Pengelupasan batu merupakan pelarutan unsur-unsur kimia 
dan diikuti proses penguapan. Proses ini dipicu oleh kondisi nat batu yang sangat rapat sehingga terjadi stagnasi air dan pertumbuhan mikroorganisme yang menyebabkan air tidak dapat mengalir dengan lancar. $\mathrm{D}$ at a sementasi dan penggaraman dapat dilihat pada grafik di bawah ini :

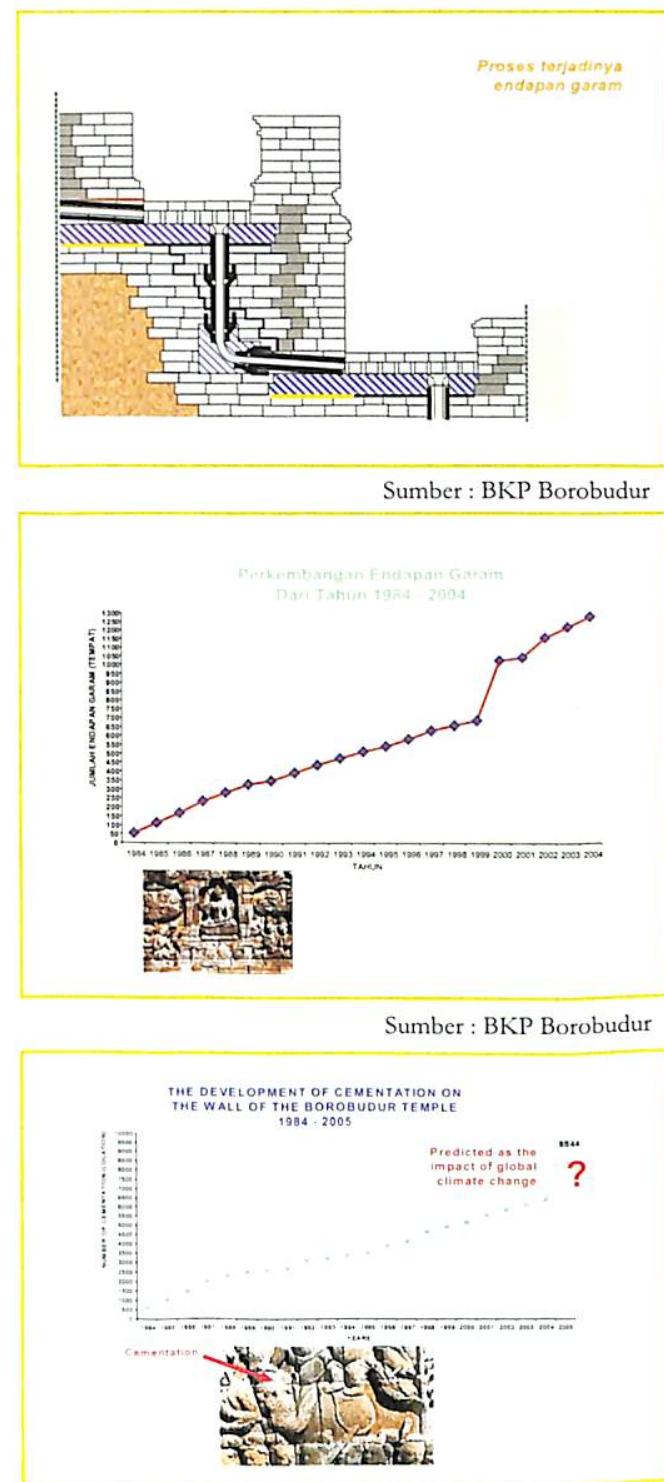

Sumber : BKP Borobudur

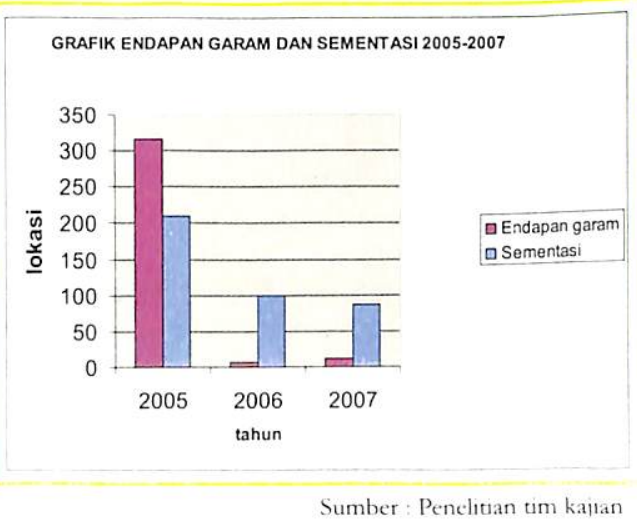

e. Retakan

Retakan terjadi disebabkan oleh adanya proses adaptasi dari struktur bangunan (stress) dan faktor lingkungan klimatologi. Data retakan dapat dilihat pada grafik di bawah ini :

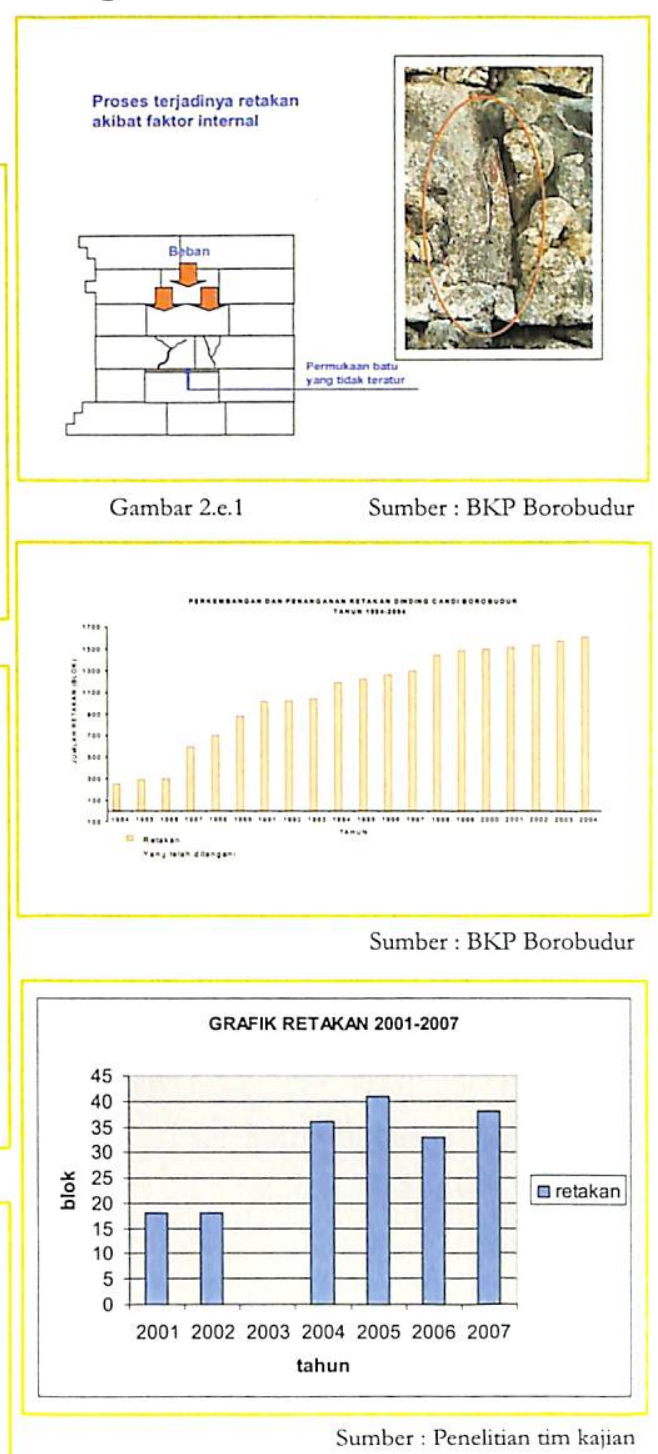

f. Keausan

Batu yang terdapat penyakit apabila tidak dilakukan tindakan konservasi maka kerusakannya akan terus meningkat menjadi aus. Untuk batu yang berelief lama kelamaan tonjolan bentuknya akan hilang. Data keausan tahun 2008 dapat dilihat pada tabel di bawah ini:

\begin{tabular}{lcccccc}
\multicolumn{7}{c}{ Jumlah batu yang mengalami keausan } \\
$\quad$ Dinding & Tk I & Tk II & Tk III & Tk IV & Jumlah \\
Utara & 7 & 10 & 10 & 7 & 34 \\
Timur & 5 & 8 & 11 & 4 & 28 \\
Selatan & 3 & 11 & 7 & 3 & 24 \\
Barat & 1 & 5 & 8 & 5 & 19 \\
& 16 & 34 & 36 & 19 & 105
\end{tabular}

\section{F. Data Kualitas Udara}

Data kualitas dan kandungan terdiri dari kadar $\mathrm{SO}_{2}$, $\mathrm{CO}_{2}$ dan $\mathrm{NO}_{2}$ diudara.

Pengambilan sampel udara untuk kandungan $\mathrm{SO}_{2}, \mathrm{CO}$ dan $\mathrm{NO}$ dilakukan pada empat titik, 1 titik pada area zona 2 disekitar loket masuk (PT.TWCB) ke candi, 2 titik di area zona 1 pada halaman candi dan 1 titik di sekitar stupa pusat candi.

Pengambilan sampel pada masing-masing lokasi dilakukan selama 30 menit untuk satu parameter.

\begin{tabular}{|c|c|c|c|c|}
\hline \multirow[b]{2}{*}{ No } & \multicolumn{4}{|c|}{$\begin{array}{l}\text { Tabel. Hasil analisa Kualitas Udara di area Zona } 1 \text { dan Zona } 2 \\
\text { Candi Borobudur Tahun } 2009\end{array}$} \\
\hline & Lokasi & Parameter & BAKU MUTU & Hasil Analisa \\
\hline \multirow[t]{3}{*}{1} & Loket & $\mathrm{NO}_{2}$ & 316 & 36,55 \\
\hline & Zona 2 & $\mathrm{SO}_{2}$ & 632 & 92,43 \\
\hline & & $\mathrm{CO}$ & $15.000,00$ & 110,33 \\
\hline \multirow[t]{3}{*}{2} & Sisi Timur Laut & $\mathrm{NO}_{2}$ & 316 & 65,58 \\
\hline & Zona 1 & $\mathrm{SO}_{2}$ & 632 & 132 \\
\hline & & $\mathrm{CO}$ & $15.000,00$ & 334,45 \\
\hline \multirow[t]{3}{*}{3} & Sisi Barat Laut & $\mathrm{NO}_{2}$ & 316 & 50,45 \\
\hline & Halaman & $\mathrm{SO}_{2}$ & 632 & 107,86 \\
\hline & Zona 1 & $\mathrm{CO}$ & $15.000,00$ & 826,4 \\
\hline \multirow[t]{3}{*}{4} & Stupa Pusat & $\mathrm{NO}_{2}$ & 316 & 38,39 \\
\hline & Zona 1 & $\mathrm{SO}_{2}$ & 632 & 77,93 \\
\hline & & $\mathrm{CO}$ & $15.000,00$ & $1.552,15$ \\
\hline
\end{tabular}

\section{G. Data Jumlah Pengunjung Candi Borobudur}

Dari hasil pengumpulan data pengunjung dari tahun 1984 sampai 2007 diketahui bahwa jumlah pengunjung yang datang sebesar 43.328 .414 orang dengan rincian jumlah pertahunnya adalah sebagai berikut:

Tabel Jumlah Penguniung Candi Borobudur dari tahun 1984 - 2007

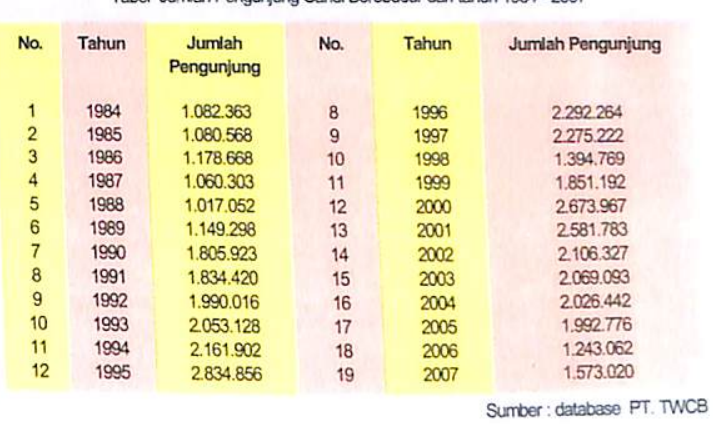




\section{H. Pengertian Pemanasan Global}

Pemanasan global (global warming) adalah adanya proses peningkatan suhu rata-rata atmosfer, laut, dan bumi dari tahun ke tahun. Menurut para ahli baik nasional maupun internasional menyatakan bahwa peningkatan temperatur rata-rata global disebabkan oleh meningkatnya konsentrasi gas-gas rumah kaca akibat aktivitas manusia melalui efek rumah kaca (greenhouse effect). Meningkatnya suhu global diperkirakan akan menyebabkan perubahan-perubahan yang lain seperti naiknya permukaan air laut, meningkatnya intensitas fenomena cuaca yang ekstrim, serta perubahan jumlah dan pola presipitasi. Akibat pemanasan global yang lain diantaranya adalah terpengaruhnya hasil pertanian dan mencairnya gletser, misalnya di pegunungan Himalaya. Literatur menunjukkan kenaikan temperatur global terjadi pada kisaran $1,5^{\circ} \mathrm{C} 40^{\circ} \mathrm{C}$ pada akhir abad 21 (http: L Lgeo.ugm.ac.id).

Terjadinya proses ini di bumi dimulai dari kenyataan bahwa energi panas yang dipancarkan berasal dari dari matahari yang masuk ke bumi menciptakan cuaca dan iklim serta panas pada permukaan bumi secara global, Pemanasan global terjadi ketika ada konsentrasi gas-gas tertentu yang dikenal dengan gas rumahkaca, yg terus bertambah di udara, Hal tersebut disebabkan oleh tindakan manusia, kegiatan industri, khususnya CO 2 dan chlorofluorocarbon. Yang terutama adalah karbon dioksida, yang umumnya dihasilkan oleh penggunaan batubara, minyak bumi, gas dan penggundulan hutan sertapembakaran hutan. Asam nitrat dihasilkan oleh kendaraan dan emisi industri, sedangkan emisimetan disebabkan oleh aktivitas industri dan pertanian.

Segala sumber energi yang terdapat di bumi berasal dari matahari. Sebagian besar energi tersebut dalam bentuk radiasi gelombang pendek termasuk cahaya. Ketika energi ini mengenai permukaan bumi, terjadi perubahan dari cahaya menjadi panas. Bumi akan menyerap sebagian panas dan memantulkan kembali sisanya. Sebagian dari panas ini sebagai radiasi infra merah gelombang panjang ke angkasa luar. Akan tetapi sebagian panas tetap terperangkap di atmosfer bumi akibat menumpuknya jumlah gas rumah kaca antara lain uap air, karbondioksida $\left(\mathrm{CO}_{2}\right)$, metana $\left(\mathrm{CH}_{4}\right)$, dinitrooksida $\left(\mathrm{N}_{2} \mathrm{O}\right)$, dan CFC yang menjadi perangkap gelombang radiasi ini. Gas-gas ini menyerap dan memantulkan kembali radiasi gelombang yang dipancarkan bumi sehingga panas tersebut akan tersimpan di permukaan bumi. Hal tersebut terjadi berulang-ulang dan mengakibatkan suhu rata-rata tahunan bumi terus meningkat (http://id.wikipedia.org/wiki/Pem anasan_global).

Sebenarnya efek rumah kaca sangat dibutuhkan oleh semua makhluk hidup di bumi ini, karena bumi ini akan menjadi sangat dingin. Namun karena jumlah gas-gas tersebut telah berlebih di atmosfer, sehingga pemanasan global menjadi akibatnya. Pemanasan global mengakibatkan dampak yang luas bagi lingkungan bio-geofisik dan aktivitas sosial-ekonomi masyarakat. Perubahan iklim akibat pemanasan global secara general dirasakan oleh seluruh dunia pada saat ini yaitu terjadinya perubahan pola misalnya pergeseran iklim sehingga makin panjang musim panas dan makin pendek musim hujan, hal ini berdampak turunnya produksi pertanian. Selain itu naiknya permukaan air laut, meningkatnya cuaca secara ekstrim, misalnya pada suatu daerah yang dahulunya sejuk dan dingin kondisi sekarang semakin hari semakin panas. Meningkatnya suhu juga menimbulkan wabah penyakit endemik lama dan baru secara merata dan terus bermunculan (http://www.walhi.or.id).

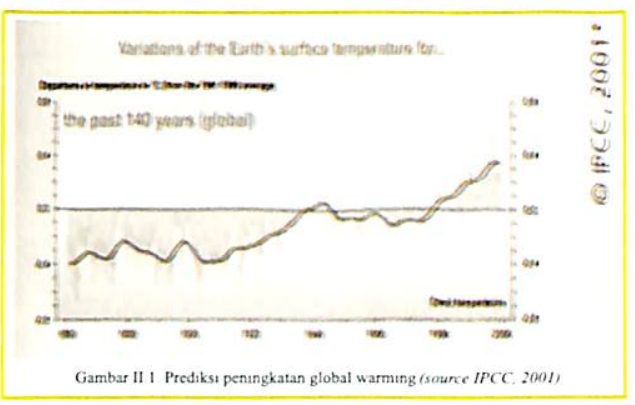

\section{Pencemaran Udara Penyebab}

Secara umum pencemaran udara disebabkan oleh 2 faktor (wardhana,2001) yaitu:

a. Faktor Internal (alamiah) contohnya :

1. Debu

2. Debu/abu akibat letusan gunung berapi

3. Proses pembusukan sampah

b. Faktor Eksternal (manusia) :

1. Hasil pembakaran bahan baker

2. $\mathrm{S} a \mathrm{~m} \mathrm{pah}$ y a $\mathrm{ng}$ disebabkan karena faktor industri (asap, debu, dll)

3. Pemakaian zat kimia yang disebarkan ke udara

\section{Komponen Pencemaran Udara}

Menurut Wardhana 2001 komponen pencemaran udara terdiri dari :

a. Karbon Monoksida (CO)

b. Nitrogen Oksida ( $\mathrm{NO}_{\mathrm{x}}$ )

c. Belerang Oksida (SOx)

d. Hidrokarbon $(\mathrm{HC})$

e. Partikel

f. Timah Hitam 


\section{J. Dampak Pemanasan Global Terhadap Batu Candi Borobudur}

\section{Terjadinya Trend dan Variabilitas Iklim}

B e rdasarkan data klimatologi suhu udara, kelembapan udara, curah hujan dan hari hujan, arah dan kecepatan angin, lama penyinaran, jumlah penguapan air, dan intensitas penyinaran matahari, menunjukkan bahwa terjadinya trend (kecenderungan atau arah gejala) adanya kenaikan grafik serta adanya variabilitas iklim. Indikasi secara umum dampak pemanasan global diantaranya yaitu kenaikan suhu yang eksterm di atas 37 ${ }^{\circ} \mathrm{C}$ dan terjadinya pergeseran iklim. Kenaikan suhu yang terjadi di kawasan Borobudur belum signifikan $\mathrm{karena} \quad \mathrm{laju}$ perkembangannya belum menunjukkan kenaikan suhu secara terus menerus setiap tahunnya. Namun berdasarkan data suhu udara maksimum harus cermati secara seksama karena pernah mencapai $37{ }^{\circ} \mathrm{C}$. Berikut ini pengamatan data suhu udara maksimum dari tahun 19702007 sebagai berikut :

1) Pada tahun 1972, 1980, dan 1993 suhu udara maksimum berada pada angka $37,0^{\circ} \mathrm{C}$. Siklusnya dari tahun 1972 ke 1980 adalah 8 tahun dan dari 1980 ke 1993 adalah 13 tahun

2) Pada tahun 19941997 suhu udara maksimum mencapai $35,5^{\circ} \mathrm{C}$ 36, 5 C
3) Pada tahun 19982003 suhu maksimum antara $34,0^{\circ} \mathrm{C} 35,5^{\circ} \mathrm{C}$

4) Pada tahun 20042005 suhu maksimum antara $32,8^{\circ} \mathrm{C} 33,4{ }^{\circ} \mathrm{C}$

5) Pada tahun 2006 suhu maksimum antara 35,5 ${ }^{\circ} \mathrm{C} 36,5{ }^{\circ} \mathrm{C}$

6) Pada tahun 2007 suhu maksimum antara 33,0 ${ }^{\circ} \mathrm{C} 35,0{ }^{\circ} \mathrm{C}$

Berdasarkan pengamatan data suhu udara maksimum dari tahun $1970 \quad 2007$ menunjukkan bahwa angka tertinggi suhu udara maksimum adalah $37,0{ }^{\circ} \mathrm{C}$. Suhu udara maksimum 37,0 ${ }^{\circ} \mathrm{C}$ belum menunjukkan masuknya iklim kawasan Borobudur dalam kriteria pengaruh pemanasan iklim global. Namun apabila dilihat siklusnya terdapat indikasi terjadinya kenaikan dari tahun ke tahun semakin meningkat antara $36,5{ }^{\circ} \mathrm{C}$ $37,0{ }^{\circ} \mathrm{C}$, hal ini sudah dapat dijadikan petunjuk bahwa adanya dampak pemanasan global terhadap iklim di kawasan Borobudur, meskipun belum signifikan. Dengan demikian, dalam jangka panjang pengamatan iklim dari stasiun klimatologi harus dipantau secara terus menerus dan dievaluasi terhadap perubahan-perubahan yang terjadi sebagai antisipasi terhadap kerusakan batubatu Candi Borobudur.

Berdasarkan pengamatan data jumlah curah hujan dari tahun 1970 $200^{-7}$ menunjukkan bahwa pada bulan Januari s/d Maret curah hujan cukup tingegi karena musim penghujan. kemudian jumlah curah hujan menurun sampai bulan Mei. Mulai bulan Juni s/d September curah hujan semakin turun karena memasuki musim kemarau. Pada bulan September curah hujan mulai meningkat lagi karena memasuki musim penghujan, puncaknya pada bulan November $\mathrm{s} / \mathrm{d}$ Desember curah hujan mencapai angka tertinggi $621 \mathrm{~mm}$ pada bulan November 1995. Dari data jumlah curah hujan tertinggi di atas $500 \mathrm{~mm}$ selama 37 tahun dapat diamati sebagai berikut:

1) Tahun 1979 jumlah curah hujan tertinggi $534 \mathrm{~mm}$ jatuh pada bulan Mei

2) Tahun 1982 jumlah curah hujan tertinggi $573 \mathrm{~mm}$ jatuh pada bulan Januari

3) Tahun 1986 jumlah curah hujan tertinggi $565 \mathrm{~mm}$ jatuh pada bulan Maret

4) Tahun 1987 jumlah curah hujan tertinggi $600 \mathrm{~mm}$ jatuh pada bulan Januari

5) Tahun 1989 jumlah curah hujan tertinggi $566 \mathrm{~mm}$ jatuh pada bulan Februari

6) Tahun 1994 jumlah curah hujan tertinggi $616 \mathrm{~mm}$ jatuh pada bulan Maret

7) Tahun 1995 jumlah curah hujan tertinggi $621 \mathrm{~mm}$ jatuh pada bulan November

8) Tahun 2004 jumlah curah hujan tertinges $585 \mathrm{~mm}$ jatuh pada bulan Desember 
Berdasarkan data klimatologi Borobudur tersebut di atas tampak adanya perubahan pola atau pergeseran iklim, musim kemarau lebih panjang daripada musim hujan, pergeseran puncak musim hujan, sehingga perlu diperhatikan dan diamati secera teliti pergeseran iklim tersebut dengan j u m la h a n g k a kenaikannya. Adanya perubahan iklim global yang telah dialami di beberapa wilayah di Indonesia, meskipun di kawasan Borobudur belum tampak signifikan perubahan iklimnya, namun petunjuk adanya tanda-tanda dampak pemanasan global sudah terlihat dari data stasiun klimatologi.

Perubahan iklim global berupa terjadinya perubahan pola atau pergeseran iklim juga n a m pak pada data pengamatan klimatologi di Borobudur. Berdasarkan laporan Monitoring Dampak Lingkungan tahun 2007, tercatat data curah hujan sepanjang 6 tahun terakhir, menunjukkan adanya pergeseran puncak musim hujan dalam siklus 2 tahunan. Pada tahun 2002 dan 2003 puncak musim hujan terjadi pada bulan Februari, tahun 2004 dan 20105 pada bulan Desember, tahun 2006 pada bulan Januari, dan tahun 20(1) 7 curah hujan tertinggi terjadi pada bulan Desember. Musim kemarau terpanjang terjadi pada tahun 20106, dimulai dari bulan Juni sampai November. Berdasarkan data kelembapan dan temperatur udara dari tahun 20022007 belum menunjukkan perubahan yang berarti (Ari Swastikawati, 2007: 19).

\section{Analisa Kualitas udara}

Dari hasil pengambilan data kualitas udara di lokasi zona 1 dan 2 serta perbandingan dengan kualitas udara pada tahun 2000 dan 2005 ada beberapa korelasi data yaitu :

a. kadar $\mathrm{NO}_{2}$ di zona 2 ( areal parkir ; loket) dan zona 1 ( stupa pusat ; teras candi) mengalami $\mathrm{p}$ e $n$ u $r$ u $n$ a $n$ dibandingkan dengan $\mathrm{t}$ a h u n - t a h u n sebelumnya. Dari 72,261 ppm pada tahun $2000 \mathrm{ke}$ 36,55 ppm pada tahun 2009

b. Kadar $\mathrm{SO}_{2}$ di zona 2 (areal parkir) mengalami kenaikan, tetapi masih berada di bawah standar baku mutu.

c. Kadar $\mathrm{SO}_{2}$ di zona 1 (stupa pusat dan teras) mengalami kenaikan dari 8,43 ppm pada tahun 2000 ke 77,93 ppm pada tahun 2009

d. Kadar $\mathrm{CO}_{2}$ baik di zona 1 maupun zona 2 masih di bawah standar baku mutu.

\section{Korelasi Antara Tingkat Kerusakan Batu Dengan Iklim}

Berdasarkan parameter tingkat kerusakan pada batu Candi Borobudur yang terdiri dari pertumbuhan jasad, postule dan lubang alveol, pengelupasan, endapan garam dan sementasi, retakan, serta keausan dari tahun 1984 2007 tampak pada grafik jumlah kerusakannya mengalami kenaikan cukup signifikan antara tahun 1984 2004. Grafik kenaikan yang cukup signifikan tersebut yaitu endapan garam dari tahun $1998 \quad 2000$, pengelupasan antara tahun 19952000 , sementasi antara tahun 2003 2004, alveol antara tahun 1998 2002, dan retakan antara tahun 1994 1997. Ada prediksi bah wa penambahan jumlah kerusakan yang cukup signifikan tersebut dikarenakan adanya pengaruh iklim global.

$\mathrm{Nam} \mathrm{un} \mathrm{d} \mathrm{a} \mathrm{l}$ a $\mathrm{m}$ perkembangan selanjutnya, sesudah tahun 2000 grafik tingkat kerusakan ternyata mengalami penurunan dan ada pula pada posisi stabil tidak terdapat jumlah kerusakan yang signifikan. Data jumlah kerusakan yang mengalami penurunan tersebut yaitu:

1) Pertumbuhan jasad mulai tahun 20042007 grafik tingkat k e r u s a k n n y a mengalami penurunan

2) Postule dan lubang alveol mulai tahun 2005 2007 grafik tingkat k e r u s a k n n y a mengalami penurunan

3) Pengelupasan mulai tahun 20042007 grafik tingkat kerusakannya mengalami penurunan

4) Endapan garam dan sementasi mulai tahun 200520107 grafik tingkat 
ke rus a kan n a mengalami penurunan

5) Retakan mulai tahun 20042007 grafik tingkat $\mathrm{k}$ e r u s a k a n n a mengalami penurunan dibandingkan sebelum tahun 2000, kemudian pada posisi stabil antara tahun 20042007

Hasil observasi kerusakan batu candi kemudian direkomendasikan untuk ditangani kerusakannya melalui kegiatan konservasi baik secara mekanis maupun kimiawi (tentunya disesuaikan dengan tingkat $\mathrm{k}$ e $\mathrm{r}$ u s a k a n y a). Keberhasilan penanganan konservasi tergantung pada a s p e $\mathrm{k}$ m e $\mathrm{t}$ o d e penanganannya dan kualitas bahan kimia yang digunakan.

\section{K. Kesimpulan}

1. Berdasarkan penyajian data klimatologi dari tahun 1970 2007 menunjukkan bahwa terjadinya trend atau adanya kecenderungan kenaikan grafik serta adanya variabilitas iklim. Secara umum kriteria adanya dampak pemanasan global diantaranya yaitu kenaikan suhu yang eksterm di atas 37 "C dan terjadinya pergeseran iklim. Sehubungan dengan suhu udara maksimum kawasan Borobudur pernah mencapai $37^{\circ} \mathrm{C}$ maka harus dicermati secara seksama dan perlu dievaluasi perubahan-perubahan yang terjadi. Suhu udara maksimum 37,0 "C yang pernah terjadi di kawasan Borobudur belum menunjukkan adanya pengaruh pemanasan iklim global, namun apabila dilihat dari siklusnya terdapat indikasi terjadinya kenaikan dari tahun ke tahun semakin meningkat antara $35,5{ }^{\circ} \mathrm{C}$ $36,5^{\circ} \mathrm{C}$. Hal ini sudah dapat dijadikan petunjuk bahwa adanya dampak pemanasan global terhadap iklim di kawasan Borobudur.

2. Berdasarkan data jumlah curah hujan dari tahun 1970 2007 tampak adanya perubahan pola atau pergeseran iklim, musim kemarau lebih panjang daripada musim hujan, pergeseran puncak musim hujan, sehingga perlu diperhatikan dan diamati secera teliti pergeseran iklim tersebut. Puncak curah hujan tertinggi terjadi pada bulan November 1995 mencapai angka tertinggi $621 \mathrm{~mm}$. Adanya perubahan iklim global yang telah dialami di beberapa wilayah di Indonesia, meskipun di kawasan Borobudur belum t a m pak signifikan perubahan iklimnya, namun petunjuk adanya tandatanda dampak pemanasan global sudah terlihat dari data stasiun klimatologi.

3. Kondisi keterawatan batuan candi borobudur mengalami penurunan hal ini dapat diketahui dari data monitoring kerusakan pada batuan candi Borobudur yang dilakukan sejak pemugaran kedua (1983) sampai sekarang (2009). Dari semua parameter monitoring kerusakan batuan candi borobudur (scalling, alveole, penggaraman/sementasi. retakan, rata-rata mengalami kenaikan yang cukup signifikan. Faktor penyebab kerusakan batuan mempunyai kecenderungan disebabkan oleh perubahan klimatologi lingkungan . Curah hujan dan radiasi sinar matahari memicu adanya pertumbuhan mikroorganisme pada permukaan batu sebagai hasil dari proses fotosintesa. Adanya unsur air pada batu candi kemudian mengalami proses kimia karena adanya pengaruh penyinaran matahari menimbulkan kerusakan lainnya misalnya penggaraman, retakan, terjadinya postule dan lubang alveol, keausan, pengelupasan, dan lain sebagainya.

4. Dari data kualitas udara di sekitar candi Borobudur diketahui bahwa komponen pencemaran udara yang mengalami tingkat kenaikan adalah unsur $\mathrm{S}_{\mathrm{O}_{2}}$. Kadar $\mathrm{S}_{\mathrm{O} 2}$ diarea Zona 1 dan 2 candi Borobudur mengalami kenaikan dari 8,43 ppm pada tahun 2000 ke 77,93 ppm pada tahun 2009 ( masih dibawah standart baku mutu). Untuk komponen lainnya yaitu $\mathrm{N}_{12}$ dan $\mathrm{C}_{12}$ tidak mengalami kenaikan.

5. Kenaikan kadar pencemaran udara $\mathrm{SO}_{2}$ di sekitar candi Borobudur bisa disebabkan karena asap kendaraan, pembusukan sampah , pemakaian zat kimia yang tersebar di udara dan berkurangnya lahan hijau. untuk faktor asap kendaraan bisa dikorelasikan dengan naiknya jumlah kendaraan untuk jenis mobil rany berada di areal parkir candi Borsobudur, vaitu sebesar 
133,704 pada tahun 2000 naik menjadi 136.717 pada tahun 2009.

\section{Saran}

1. Peningkatan dan pengembangan metode monitoring klimatologi dan monitoring keterawatan batu candi Borobudur untuk menghasilkan data yang lebih lengkap dan akurat yang dapat digunakan sebagai analisis pada penelitian penelitian lainnya.

2. Penanaman pohon pohon/tanaman disekitar candi Borobudur sebagai usaha perluasan lahan hijau $\mathrm{untuk}$ menyerap komponen-komponen pencemaran udara yang ada.

3. Meminimalisir penggunaan bahan kimia untuk penanganan kerusakaan batu candi borobudur, terutama yang tersebar di udara.

4. Mengembangkan metode konservasi batu candi B orobudur secara tradisional dan ramah lingkungan.

5. Membuat metode sistem pengolahan sampah yang tidak mempunyai dampak terhadap kelestarian lingkungan.

6. Berkoordinasi dengan pemerintah daerah setempat dalam rangka mengatur dan mengontrol perkembangan sektor sektor industri yang berada di Zona 3 candi Borobudur. 凶

\section{Daftar Pustaka}

Anonim. 2005. Pedoman Perawatan dan Pemugaran Benda Cagar Budaya Baban Batu.
Kementerian Kebudayaan dan Pariwisata, Deputi Bidang Sejarah dan Purbakala, Asisten Deputi Urusan Kepurbakalaan dan permuseuman.

2008. Pemanasan

Global. Wikipedia Indonesia, ensiklopedia bebas berbahasa

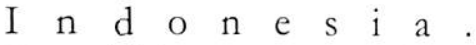
Http://id.wikipedia.org/wiki /Pemanasan_global. 2007. Pemanasan Global. Fakultas Geografi UGM.

Ari Swastikawati, dkk. 2007. Laporan Monitoring Dampak. Lingkungan. Borobudur: Balai Konservasi Peninggalan Borobudur, Departemen Kebudayaan dan pariwisata.

Aris Munandar. 2004. Observasi Klimatologi dan Kegunaannya dalam Konservasi BCB. Makalah Diklat Konservasi dan Pemugaran Tingkat Menergah, Balai Konservasi Peninggalan Borobudur.

2002. Laporan

Konservasi Candi Borobudur Pascapemugaran. Bagian Provek Pemanfaatan Peninggalan Sejarah dan Purbakala Candi Borobudur.

Dukut Santoso. 2000. Pemantapan Standar Konservasi II Perawatan dan Monitoring Pasca Konservasi Bangunan Cagar Budaya. Balai Studi dan Konservasi Borobudur, Direktorat Perlindungan dan pembinaan Peninggalan sejarah dan Purbakala.

Hr. Sadirin. 1991. Evaluasi Data Iklim Borobudur. Proyek Konservasi Candi Borobudur, Departemen Pendidikan dan Kebudayaan, Jakarta.

Sudibyo, dkk. 1996/ 1997. Iklim Borobudur. Balai Studi dan Konservasi Borobudur,
Departemen Pendidikan dan Kebudayaan.

Sudjono. 1987. Pokok-Pokok. Pengolaban Data Klimatologi. Lembaga Meteorologi dan Geofisika, Departemen Perhubungan, Jakarta.

Sukronedi, dkk. 2000. Studi Dampak: Lingkungan Candi Borobudur. Balai Studi dan Konservasi Borobudur, Departemen Pendidikan dan Kebudayaan.

Tjasyono, B.HK. 1986. Iklim dan Lingkungan. Cendekia Jaya Utama, Bandung.

Waryono, R. Ali dan D.H. Gunawan. 1987. Pengantar Meteorologi dan Klimatologi. РT. Bina Ilmu surabaya.
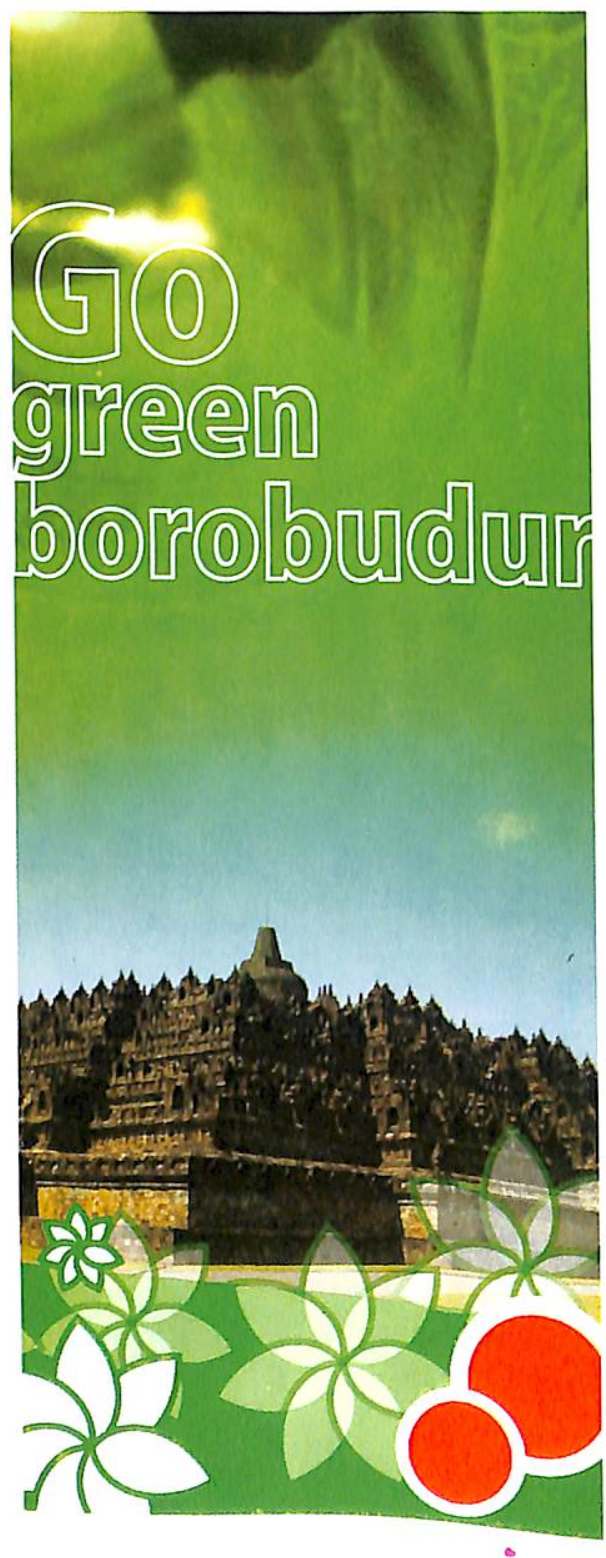